\title{
TAN Hot Shop and Support Facility Utilization Study
}

\author{
B. A. Picker
}

November 2001

Idaho National Engineering and Environmental Laboratory Bechtel BWXT Idaho, LLC 


\title{
TAN Hot Shop and Support Facility Utilization Study
}

\author{
Bobby A. Picker
}

November 2001

\section{Idaho National Engineering and Environmental Laboratory Idaho Falls, Idaho 83415}

Prepared for the

U.S. Department of Energy

Assistant Secretary for Environmental Management

Under DOE Idaho Operations Office

Contract DE-AC07-99ID13727 


\begin{abstract}
Impacts to the U.S. Department of Energy (DOE) complex caused by early closure (prior to 2018) and Demolition and Dismantlement (D\&D) of the Test Area North (TAN) hot shop and its support facilities are explored in this report. Various possible conditions, such as Standby, Safe Store and Lay-up, that the facility may be placed in prior to eventually being turned over to D\&D are addressed. The requirements, impacts, and implications to the facility and to the DOE complex are discussed for each condition presented in the report. Some details of the report reference the Idaho National Engineering and Environmental Laboratory (INEEL) Spent Nuclear Fuel Life Cycle Baseline Plan, the INEEL 2000 Infrastructure Long Rang Plan, and other internal INEEL reports.
\end{abstract}




\section{SUMMARY}

The Idaho National Engineering and Environmental Laboratory (INEEL) Spent Nuclear Fuel (SNF) Life Cycle Baseline Plan called for maintaining operations at Test Area North (TAN) until 2018. The INEEL "2000

Infrastructure Long Range Plan" released in August 2000 calls for the closure of TAN by the end of FY 2007 with completion of Demolition and Dismantlement (D\&D) activities by 2018. This report indicates that operations at TAN should continue until the end of FY 2005, at which time the storage casks will be moved to the Idaho Nuclear Technology and Engineering Center (INTEC). Response to any potential leaks could be handled by the use of various INTEC facilities such as CPP-666. In addition when the SNF Dry Storage Project (DSP) facility becomes operational, it will provide another location for response to potential cask leaks on those casks that it is capable of handling.

Following SNF and abnormal waste removal from TAN, the facility would be eligible for shutdown and eventual D\&D activities. The shutdown would proceed by stages. The first is the Standby stage. The second and longest stage is the Safe Store stage. Safe Store is the recommended stage and would be the most cost-effective condition in which to leave the facility while efforts are made to find new programs or sponsors for its unique capabilities. During the Safe Store time period any D\&D efforts at TAN would be only to buildings or structures that are not critical for an eventual restart of TAN-607 Hot Shop (THS). Finally, the facility is placed in the third stage, Lay-up. At this stage the facility is prepared for final D\&D activities to all remaining buildings and structures. Once the facility reaches Lay-up, the ability to restart and the cost of restart are too great to overcome. With a restart no longer viable, it becomes more prudent for U.S. Department of Energy (DOE) to design and build a new facility should the need for such capabilities as TAN provided be required in the DOE complex.

Earlier closure, than 2018, which is identified in the SNF long-range plan, of the THS and support facilities assumes some risk. If the storage casks leak or need maintenance for any reason, the THS would need to be reconditioned as required to perform work on the casks. Based on history, it is felt that the likelihood of the casks needing maintenance is very low, but the impact in terms of cost and response time to affect any repairs would be very significant. Until the SNF DSP is fully operational, it is considered best to leave the casks closest to the facilities that can provide maintenance if needed.

The Specific Manufacturing Capability (SMC) facilities and operations located in the TAN area would not be adversely affected by the shutdown of TAN. The impact of the TAN shutdown would require that tasks currently done around the THS area be moved to its main facility location west of the THS. Other changes may require constructing new facilities at the SMC to replace facilities closed by the TAN shutdown.

All dates presented in this document are based on the best available data and subject to change. Changes can be caused by many factors such as funding changes, priority changes within the DOE complex, and national priority changes. 


\section{CONTENTS}

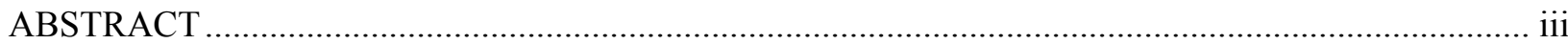

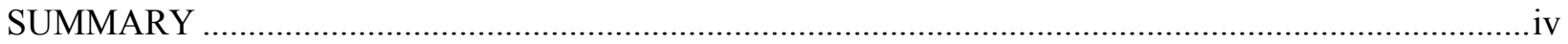

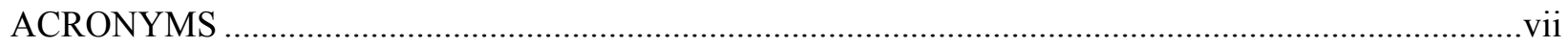

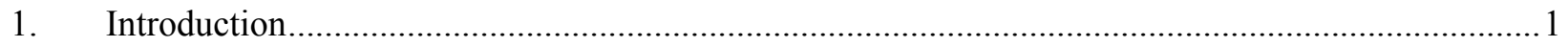

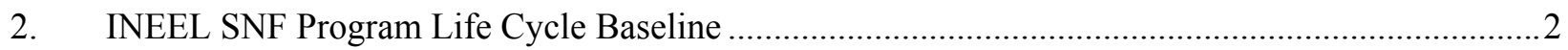

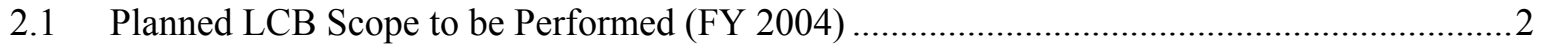

2.2 Planned LCB Scope to be Performed (FY 2005-FY 2018) ..............................................2

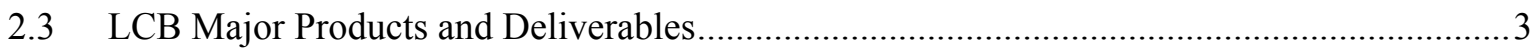

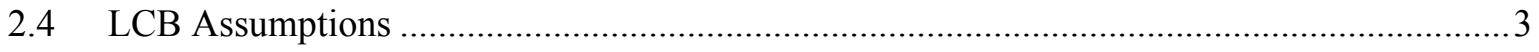

2.5 LCB Emptied Spent Nuclear Fuel Facilities Milestone Log .............................................

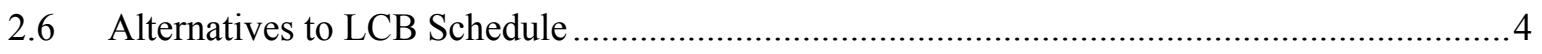

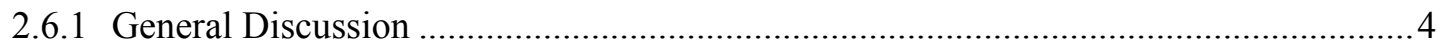

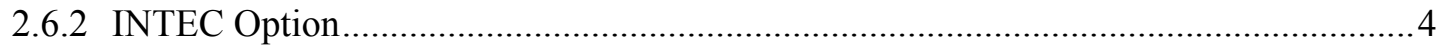

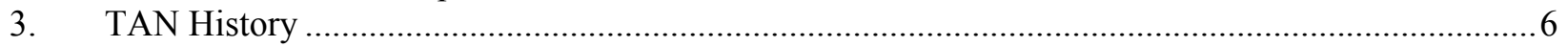

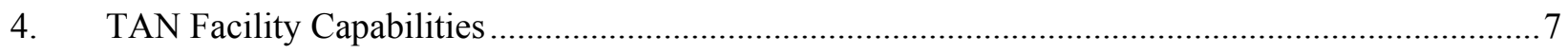

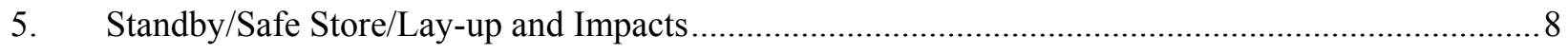

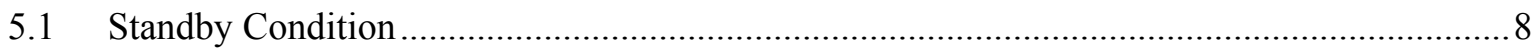

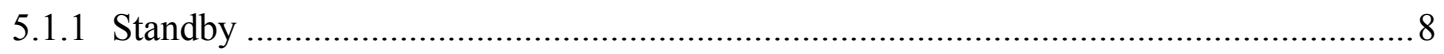

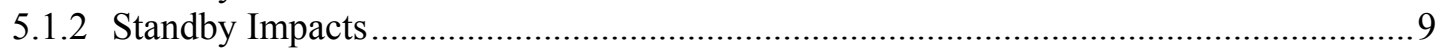

5.1.3 Standby Implications to DOE Complex...........................................................

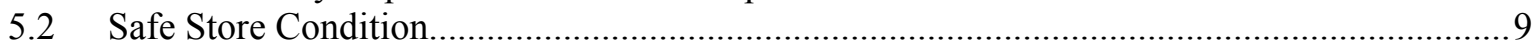

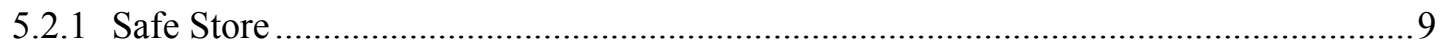

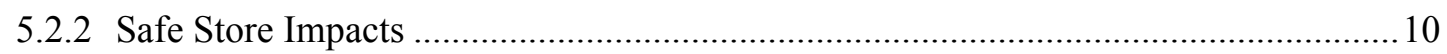

5.2.3 Safe Store Implications to DOE Complex …........................................................ 11

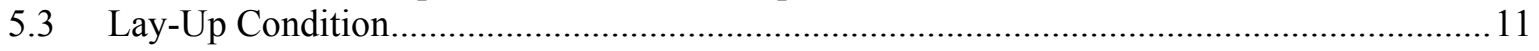

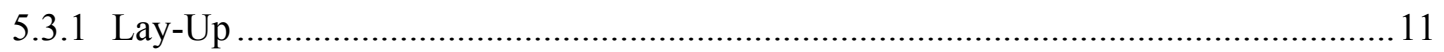

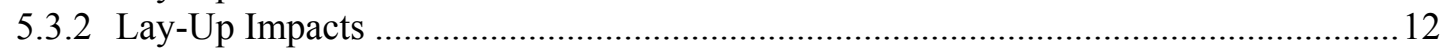

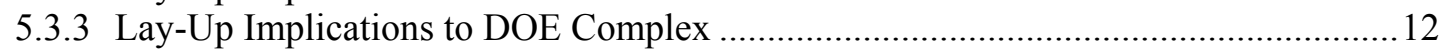

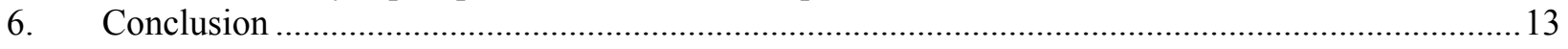

Appendix A-Test Area North and Hot Shop Facility Description...................................................... 
Appendix B - Costs Associated with INTEC Option

B-1

\section{TABLES}

1. Cost to establish, maintain, and restart from various facility conditions ..................................... 12 


\section{ACRONYMS}

D\&D Demolition and Dismantlement

DOE U.S. Department of Energy

DSP Dry Storage Project

GPU General Public Utilities

INEEL Idaho National Engineering and Environmental Laboratory

INTEC Idaho Nuclear Technology and Engineering Center

LCB Life Cycle Baseline

LCPP Life Cycle Planning Package

LTSM Long Term Storage and Monitoring

MGR Monitored Geological Repository

RC\&S regulations, codes and standards

SAR Safety Analysis Report

SMC Specific Manufacturing Capability

SNF Spent Nuclear Fuel

TAN Test Area North

TANO Test Area North Operations

THS TAN-607 Hot Shop

TMI Three Mile Island

TSF Technical Support Facility

TSR Technical Specification Requirements

WVDP West Valley Demonstration Project 


\section{Tan Hot Shop and Support Facility Utilization Study}

\section{INTRODUCTION}

Test Area North (TAN) is the northernmost developed area within the Idaho National Engineering and Environmental Laboratory (INEEL). It was originally established to support the Aircraft Nuclear Propulsion Program, which operated from 1954 to 1961. Since 1961, TAN buildings have been adapted for use by various other programs, such as Test Area North Operations (TANO). The current programs operating at TAN are the INEEL Spent Nuclear Fuel (SNF) Program and the Specific Manufacturing Capability (SMC).

The INEEL SNF Program mission at TAN, specifically TAN-607 and its support complex, is rapidly coming to a conclusion. This paper will discuss the currently defined work scope in the Life Cycle Baseline (LCB) and the schedule for SNF activities at TAN along with options for expedited movement to shutdown conditions or closure of the TAN facilities.

The INEEL Infrastructure Long Range Plan for 2000 provides a discussion of the projected future of TAN. This plan provides detail pertaining to the status and condition of all the buildings and structures at TAN along with other data on TAN. Another report, Test Area North Readiness Plan Development (INEEL/INT-01-00096), gives more specific details and provides various options and recommendations for TAN during the period of 2005 to 2010. 


\section{INEEL SNF PROGRAM LIFE CYCLE BASELINE}

The current approved LCB for the TAN, as defined by the INEEL SNF Program and described in greater detail in Section 2.2, identifies work scope and activities through the year 2018 for TANO. The current work scope for TANO includes the transfer of LOFT/commercial fuel from the TAN-607 storage pool to dry storage casks. The casks will then be located on the SNF Storage Pad, TAN-791. Following the removal of the SNF currently in storage in TAN-607, the facility would be emptied allowing a change in status to occur. Section 2.6 describes the differences between the LCB and other alternatives studied for the future of TAN.

\subsection{Planned LCB Scope to be Performed (FY 2004)}

1. Facility Maintenance and Operations:

a. $\quad$ Provide for maintenance activities associated with the TAN-607 Hot Shop (THS), Warm Shop, and supporting infrastructure through an effective preventive maintenance program and an efficient corrective maintenance system to prevent deterioration of the facilities, and to minimize safety and health hazards.

b. Provide operational and facility surveillance, monitoring, operational and emergency training, sampling and regulatory activities.

c. Provide Environmental, Safety, and Health (ES\&H) oversight by industrial safety, fire protection, radiological control engineering, and technicians; quality assurance, chemical management, and environmental engineers; industrial hygienist; and emergency preparedness of TANO activities to minimize the potential for safety and health related incidents.

d. Manage the specified types of waste generated at TAN from pregeneration planning through disposition at a treatment, storage, or disposal facility.

e. Maintain the Safety Analysis Report/Technical Specification Requirements (SAR/TSR) safety documentation per the requirements as applicable.

f. Maintain Management/Supervisor Oversight activities at the "minimum-safe" compliance levels.

2. Monitoring and surveillance of fuel casks stored on the TAN/Technical Support Facility (TSF)-791 Spent Fuel Storage Pad.

\subsection{Planned LCB Scope to be Performed (FY 2005-FY 2018)}

1. All "Facility Maintenance and Operations" activities indicated in Section 2.1 are to continue through the end of FY 2018.

2. Monitoring and surveillance of fuel casks stored on the TAN/TSF-791 Spent Fuel Storage Pad will be accomplished until they are transferred from TAN.

3. All epoxy fuel will be transferred to treatment per the approved schedule. 
4. From 2015 to 2017, all remaining SNF at TAN will be removed from storage casks and placed into transportation casks at the THS. For transportation directly to the repository,

Management/Supervisory Oversight activities will be increased during the period when fuelhandling activities are resumed.

5. Final transition of the TAN SNF facilities to D\&D will occur in FY 2018.

\subsection{LCB Major Products and Deliverables}

1. All DOE-owned SNF will be removed from the TAN/TSF-791 Spent Fuel Storage Pad and THS and sent to a national repository. Five cask loads including LOFT and Commercial SNF will be sent to the national repository by September 30, 2017.

2. All West Valley Demonstration Project (WVDP) SNF (2 cask loads) will be shipped to the Monitored Geological Repository (MGR) by September 30, 2016. (Note: WVDP SNF casks, 2 each, will go directly to the Idaho Nuclear Technology and Engineering Center (INTEC) for storage. There is no TAN support for this effort. The Life Cycle Planning Package (LCPP) change is in process.)

3. The SNF facilities will be prepared for transfer and transferred to D\&D Program in FY 2018.

\subsection{LCB Assumptions}

1. The repository will provide the casks for the shipment of SNF directly to the repository. The INEEL program/project will have the responsibility for the handling and management of transportation casks from the time they arrive at the INEEL empty until they leave for the repository.

2. Other programs may use the THS. Those programs will provide funding for the use of the facility.

3. All necessary facility and equipment upgrades, modifications, or additions and capital equipment purchases must be provided by the program/project.

4. If necessary, the Deactivation Program will construct a barrier to isolate the THS vestibule from the fuel storage pool when the pool area is turned over to them.

5. The Long Term Storage and Monitoring (LTSM) Project SNF currently stored on the TAN/TSF-791 Spent Fuel Storage Pad will have to be repackaged prior to shipment for interim or long-term storage.

6. Disposition of the General Public Utilities (GPU)/Three Mile Island (TMI) abnormal waste is out of the scope for this project.

\subsection{LCB Emptied Spent Nuclear Fuel Facilities Milestone Log}

1. WBS Element: C.1.04.02.03.01.L1, Milestone Number: 34006, Description: Transfer West Valley SNF to National Repository (2 casks), Level: E2, Plan Date: September 2016

2. WBS Element: C.1.04.02.03.01.L1, Milestone Number: 34007, Description: Transfer SNF from TAN pad to National Repository, Level: E2, Plan Date: September 2017 
3. WBS Element: C.1.04.02.03.ME.L1, Milestone Number: 36009, Description: Turnover TAN to D\&D, Level: E2, Plan Date: September 2018.

\subsection{Alternatives to LCB Schedule}

\subsubsection{General Discussion}

As discussed in Section 2.1, the approved INEEL SNF Program LCB dated January 31, 2001 defines the work scope through 2018. An accelerated path has been initiated that will maximize dry storage options and minimize current wet storage. Currently there are five dry SNF storage casks at TAN. Four of the five are loaded with SNF. The LOFT/Commercial SNF located in the TAN Storage Pool is currently expected to be loaded into the REA 2023 and the TN-24P casks by September 30, 2003. Each of the five casks is different with respect to design, dimensions, and manufacturer. The casks are stored in a vertical position on a 2-ft-thick concrete pad approximately $40 \times 95 \mathrm{ft}$ long (Reference Drawing \#165506 \& 7). Casks VSC-17 and Castor V/21 are fully loaded. Cask MC-10 is 3/4 loaded. TN-24P is currently about $1 / 4$ loaded. The REA 2023 cask is not loaded at this time. The SNF was placed in the casks in about the 1985 time frame, and the casks have been monitored since that time.

Removing the LOFT and Commercial SNF from the TAN Storage Pool will be completed by placing it in the dry storage casks located on the TAN/TSF storage pad. The commercial SNF will fully load the TN-24P cask. The LOFT SNF will be placed in the REA 2023 cask, which will then be partially loaded. Once the fuel is in the storage casks it will be left at TAN on the TAN-791 pad. The approved schedule for completion of this activity is September 30, 2003.

Other waste known as the GPU/TMI abnormal waste is out of the scope for this project. Disposition of this abnormal waste lies with GPU and the DOE. The final disposition of this waste stream also impacts the status of TAN.

Following (and in certain cases in parallel to) the removal of the identified SNF from TAN, TAN structures could begin the process of D\&D. The INEEL Infrastructure Long Range Plan provides a schedule of events concerning the disposition of TAN. The first structures and buildings are scheduled for demolition in 2001 through 2002. These initial structures and buildings are not critical to the function of THS. The next phase of demolition begins in 2006. This phase would start the removal of structures and buildings that would affect the viability of THS. After removal of the last fuel from the TAN storage pool, TAN will enter a reduced operational stage for a period between 2003 and 2006. Starting in 2007, the facility will enter a deactivation mode that will continue through 2010. Demolition is scheduled to occur between 2015 and 2018. As long as SNF in any form remains stored at TAN, the need for access to and operation of the THS would remain in order to respond to and repair cask leaks. In order to allow complete shutdown of the THS and support facilities, it is necessary to relocate the casks situated on the TAN-791 pad along with other items that are being cared for or monitored by TANO. Relocation would be required to another INEEL facility that could either currently or following modifications support the care and maintenance of the loaded casks. Disposition of the GPU/TMI abnormal waste would also be required.

\subsubsection{INTEC Option}

INTEC is the facility at the INEEL that is designated for and is capable of handling these casks. This option would require modifications at INTEC to install the support structures and systems for monitoring the casks. 
The INTEC option entails some risk in moving the casks from TAN to INTEC because they would be done along public and INEEL roadways. Although cask leaks are not anticipated, some risk is inherent from the transportation of the casks over $25+$ miles of highway to INTEC. One cask developed a leak approximately 6 years ago while in storage on the TAN/TSF-791 storage pad. THS was available to respond to the leak. The ability to respond to and recover from a cask leak must be available. The SNF Dry Storage Project (DSP) when it is fully operational at INTEC could be available to respond to certain cask leaks it may be designed to handle if necessary. (A Memorandum of Agreement/Contract Modification/Option will need to be developed with the SNF DSP facility operator to promptly respond to a cask leak.) For casks that are too large for the SNF DSP to handle, other INTEC facilities such as CPP-666 could be used to address the problem.

The casks are normally moved within the TAN facility by using the cask transporter. The cask transporter (Reference Nuclear Packaging assembly Drawing \#2011-100) is a large 58-ton straddle carrier with 6 tires capable of picking the casks up vertically to a height of 6 inches above the road/ground surface and moving them as desired on roadways having the necessary load bearing capacity. The movement of casks to INTEC will require a method of transportation to be developed using either the transporter or other means such as special trailers.

Movement of the casks to INTEC would be done over a period of months as outlined in schedules and procedures. This movement will require completion and implementation of various studies, modifications, and construction along the route and at the INTEC area. Construction at INTEC is expected to be a concrete pad, roadways, fencing, and other items to allow for care and monitoring of the casks. Cost to implement this storage at INTEC should be included to determine the total cost of the placing of TAN into Standby, Safe Store, or Lay-up. Completion of the INTEC changes will also affect the time line to get all fuel removed from TAN. A rough order of magnitude (ROM) estimate of the cost for the changes and assumptions affecting the project to accommodate the storage of casks at INTEC is summarized in Appendix B. 


\section{TAN HISTORY}

The TAN facility at the INEEL was originally established and developed in 1954 to support the Aircraft Nuclear Propulsion Program, whose purpose was to build and test the concept of a nuclear-powered airplane. The program ended in 1961. Over the years, TAN has expanded into various new missions where the facilities' unique capabilities to handle very large and radioactively contaminated components was required. These programs included nuclear and nonnuclear research and activities. Today, TANO activities include functions of packaging of the LOFT/Commercial SNF presently wet-stored in the TAN-607 fuel storage basin, storage and monitoring of SNF in dry storage at TAN-791, and manufacturing tank armor for the Department of Defense under the SMC. The SMC main operations used buildings and structures west of the area of TAN discussed in this paper. SMC is planning to move operations currently located near the THS to buildings currently available or new buildings nearer to its main facilities. 


\section{TAN FACILITY CAPABILITIES}

The TAN-607 facility is a two-story, reinforced concrete building designed and constructed in 1954 as a nuclear "hot" shop, nuclear fuel storage pool, and manufacturing facility. Beginning in 1980, the THS and associated facilities were used to inspect, research, and store material for the TMI reactor accident. TAN-607 is also used to store other SNF. Throughout the DOE complex, TAN-607 is a unique facility. A list of recognized, unique, capabilities in this "one-of-a-kind" hot shop facility and supporting infrastructure is found in Appendix A.

The TAN area provides utility functions including fire water, potable water, boiler operations, sanitary waste disposal, phone/dial room, etc., which will need resolution to allow early closure of

TAN-607. Specifically, TAN-606 and TAN-628 (exclusively in support of the SMC program) will need disposition. The utility functions listed are funded through indirect funding and do not impact early closure of the SNF Program. 


\section{STANDBY/SAFE STORE/LAY-UP AND IMPACTS}

Standby, Safe Store, and Lay-up are progressively deeper stages of deactivation. At each stage the cost and amount of effort to return the facility to an operating status would increase along with the time period to complete the reactivation process. Prior to entering each stage or step, the future need for a facility must be analyzed. This analysis would be to evaluate the cost to recover from the deactivation stage versus the time and cost to construct a new facility. In some cases, the cost to maintain a facility in an operating status can outweigh the cost to recover a facility from a deactivated condition such as Safe Store. The most important decision point is when the next stage along the path to D\&D would take a facility beyond a "point of no return." This point is where the facility has been cannibalized or allowed to deteriorate where it is no longer feasible to maintain or recover it to an operating status for future work. For this study, this condition would be when the facility is placed into the Lay-up status or turned directly over to the D\&D program. The successive steps leading to D\&D are presented below with an explanation of the condition, the impacts of each condition on the functionality of the facility, and what this condition means to the DOE complex.

Another study done for the TAN facilities and completed in February 2001, for Performance Evaluation Measurement Plan, item 5.4.1.5 addressed similar issues that are discussed in this paper. The report titled Test Area North Readiness Plan Development INEEL/INT-01-00096, February 2001, provides the data on the need for various TAN buildings to support the THS. The cost in this report is used as the basis for the options presented below. This report also makes conclusions on the most cost-effective interim status for TAN. The report describes four options that when examined and compared to the conditions defined in this paper closely matches the conditions discussed in this paper. The recommended Option 4 is a very close match for the Safe Store condition described in Section 5.2.

\subsection{Standby Condition}

\subsubsection{Standby}

Standby can be defined as keeping the equipment in a continual "state-of-readiness." Typical activities associated with the standby condition includes:

- Making equipment shaft rotations on a periodic basis to prevent "taking-a-set" scenarios where the steel in equipment shafts sag after extended nonmotion periods that would cause imbalance and inoperability upon startup

- $\quad$ Running crane bridges, trolleys, and hoists in a predetermined systematic manner

- $\quad$ Cycling large compressors to exercise the air system

- $\quad$ Cycling critical motors and pumps as appropriate

- Maintaining fluid systems full and operational with proper chemistry to prevent corrosion and deterioration

- Inspecting and maintaining all roofs, heating, ventilation, and utility systems

- $\quad$ Pressurizing applicable systems for short periods of time

- $\quad$ Keeping a single, descriptive document of all maintenance and operational activities 
- Maintaining configuration control of all documentation and procedures

- Other miscellaneous activities to allow return to operational status in a relatively short time period.

\subsubsection{Standby Impacts}

In this condition, impacts on the availability and operability of the facility are minimized. By maintaining the building, systems, equipment, and all documentation essentially as when the last program using the facility left, the activation for another program or project is minimized. The major scope to begin full operations would include:

- $\quad$ Staffing of facility to program operational requirements

- $\quad$ Training of operational staff to procedures, codes, and standards

- $\quad$ Performing system tests to ensure operability and condition of systems

- $\quad$ Developing of procedures required for new program

- $\quad$ Conducting management review/assessments etc., required by company procedures and DOE policies and orders.

\subsubsection{Standby Implications to DOE Complex}

In this condition, adverse implications to the complex are limited. The facility does cost a small portion of the total DOE budget to maintain, but the facility is always available to handle any special DOE complex or national needs for its capabilities that may develop. This condition provides the fastest response to special problems and availability to DOE needs. The cost to gear-up for new missions or programs is minimized due to the ongoing maintenance, up keep of the facility, and availability of a core staff to begin work.

\subsection{Safe Store Condition}

\subsubsection{Safe Store}

Safe Store can be defined as the front end of a process to preserve a facility for some short duration, pending identification of a new program or mission. The process for placing a facility into the Safe Store condition is summarized in the following steps:

- The current configuration of a facility is captured (i.e., drawings, procedures, work orders) and retained under configuration control. Hazards are identified and removed and mitigated through administrative or physical barriers.

- Utilities are minimized and tagged out with minimal surveillance. The THS heating would require setting to a minimum temperature to prevent low temperatures that would cause damage to the large bromine-filled viewing windows located along the THS gallery areas.

- $\quad$ No equipment is removed from the facility that is considered essential for a restart.

Safe Store involves periodic maintenance activities performed on all critical equipment by a contingent of maintenance workers on a defined schedule. A small crew of workers would perform 
preventive maintenance on critical equipment, usually every two months (these estimates are based on industry standards, predictive-modeling, and experience). In safe-store scenarios, the following activities are usually performed:

- Draining/flushing gearboxes and refilling with appropriate corrosion-resistant fluids (one-time activity)

- $\quad$ Providing fresh grease to bearings on equipment

- $\quad$ Draining and purging water from all air lines, traps, and pumps and refilling with suitable fluids if necessary

- $\quad$ Removing waste from sumps, flammables from systems, pressure from enclosed systems, tensions from springs, and accumulated loads from any devices

- $\quad$ Disabling power, removing fuses, opening large contacts, discharging capacitors, and cleaning major switches and starters

- $\quad$ Placing plastic sheeting or other means necessary over applicable equipment to protect from dust, rodents, birds, and insects

- $\quad$ Cleaning blower wheels and applying protective coatings on critical rubber components such as diaphragms and seals

- $\quad$ Checking and adding, as necessary, a suitable antifreeze mixture to fire protection systems

- $\quad$ Keeping a single, descriptive document of all maintenance and operational activities.

\subsubsection{Safe Store Impacts}

In this condition, impacts on the availability and operability of the facility are known and remain constant. The impacts to the DOE complex can be minimal or very time consuming and costly depending on the codes and standards that the facility must meet should a restart be mandated. In many cases regulations, codes, and standards (RC\&S) may require that a facility being returned to service from this condition would be required to conform with current RC\&S. Taking necessary actions to upgrade a facility to current RC\&S can be very costly and time consuming. Therefore, the most critical decision is the determination prior to entering Safe Store, of which RC\&S would be applicable upon a restart. This one issue can have more impact on the total time and cost than any other factor. In some cases this decision could result in major modification and design basis analysis that could take years to accomplish. The cost to modify and reanalyze can far overshadow the replacement of equipment due to deterioration caused by inactivity or age.

In the event that a new mission is identified, the following activities would be required.

- $\quad$ Final agreement on applicability of which set or sets of RC\&S are applicable to future operations.

- $\quad$ Engineering evaluation of facility conditions to identify the equipment required to be upgraded for compliance with agreed upon codes and standards.

- $\quad$ Detailed cost estimates are performed to identify the cost of returning the facility to the codes and standards agreed to above. 
- $\quad$ Modification of the facility as required by agreed to codes and standards.

- $\quad$ Completion of items previously identified in the Standby Impacts.

- $\quad$ Replacement of equipment such as cranes, motor control centers, etc., to achieve an operating basis as identified by Engineering evaluation.

- $\quad$ Upgrading of equipment identified in the engineering evaluation to comply with agreed upon codes and standards.

- The upgrade effort to prepare the facility for performance of the new mission or program.

\subsubsection{Safe Store Implications to DOE Complex}

The Safe Store condition can provide short-term benefits to the DOE complex by saving the cost of maintaining an operating facility following the cost to configure the facility for safe store. These savings may be realized for only a finite period of time. The time period available where a recovery to an operating status would be possible varies with the type of facility in question. For TAN, due to its unique capabilities and greatly different purpose and systems, the time period could be longer than a facility such as a nuclear reactor. The biggest drivers determining the recovery are the rate of change of applicable RC\&S. As each year passes, the amount and type of changes to RC\&S increase, and the ability to restart a facility under these initially agreed to requirements becomes more controversial and difficult. In a few cases, it is possible to restart a facility under the RC\&S that were applicable at the time of entering the safe store condition, and this possibility declines as time passes.

Another factor affecting the ability to restart a facility is the cost to gear-up for new missions or programs. This cost can vary tremendously depending on the time the facility is kept in the safe store condition and how closely the facilities' capabilities match the needs of the program desiring to use the facility. Other intangible factors such as national need or nonprogrammatic decisions can affect the final cost to a great extent. These costs are sometimes the most difficult to anticipate or estimate. At some point during the safe store condition, it becomes evident that continuing to maintain the facility in this condition is no longer viable, and steps are taken to move to the next lower level of facility status, which is the Lay-up condition, or directly to D\&D.

\subsection{Lay-Up Condition}

\subsubsection{Lay-Up}

Lay-up can be defined as a very limited amount of maintenance performed to prepare items for shutdown and walking away from the facility for some predetermined time. In this scenario the following actions would be taken:

- Initial maintenance activities would be performed as indicated in Safe Store.

- Equipment and systems would be tagged out-of-service and isolated to protect the inactive facility, environment, and personnel who may enter the facility periodically for various purposes (tours, inspections, limited housekeeping, etc.).

- Various systems could or would be cannibalized for use in other facilities.

- $\quad$ Facility configuration would be discontinued to the point where recovery would be very difficult. 
This would be the deepest level of inactivation just prior to turnover of the facility to a D\&D group for the purpose of removing the facility and returning the area to its original state.

\subsubsection{Lay-Up Impacts}

Once this condition is entered the reversal to an operating status is nearly impossible. This condition puts the facility into an inactive abandoned status with only cursory oversight. As time passes and the longer the facility remains in this status, the cost to achieve reactivation increases substantially. Only those programs with large funding and needing the special capabilities that only TAN could provide, in possibly slightly shorter time frame, would consider reactivation. At this point, the selection and building of a new facility meeting current standards and codes would most likely be more cost effective.

\subsubsection{Lay-Up Implications to DOE Complex}

When TAN is placed in the lay-up condition, the capability of the facility is lost to the DOE complex. DOE at this point is forced to design and construct a completely new facility should a future program need the type of capabilities that existed at TAN. The time and the cost to construct a new facility, while not known at this time, could easily far exceed the time and cost to maintain TAN in the Safe Store or even the Standby conditions and the time to refurbish TAN for the new program.

\section{Rough Order of Magnitude Estimate Information}

These costs are from the Test Area North Readiness Development Plan. Restart/replacement cost is associated with placing the facility back into an operational condition. Industry standards describe replacement of critical equipment for the scenarios presented. Lay-up would entail replacement of approximately $50 \%$ of the facility equipment. Standby would require approximately $5 \%$ equipment replacement, and Safe-Store would require approximately $25 \%$ equipment replacement. The estimated value of equipment just within the TAN-607 facility is approximately $\$ 18 \mathrm{M}$. The estimated costs associated with each of the three scenarios described above are provided in Table 1. These estimates are based on a time period from FY 2004 until FY 2010 with a restart in FY 2010 (cost for restart may be reduced for an earlier startup pending engineering evaluation of facility conditions at time decision is made to restart).

In all scenarios presented in Table 1, an Operational Readiness Review would be required to restart operations. This restart cost would be a requirement for any new program/project requesting use of the TAN-607 facility.

Table 1. Cost to establish, maintain, and restart from various facility conditions.

\begin{tabular}{|c|c|c|c|c|}
\hline Condition & $\begin{array}{c}\text { Initial } \\
\text { Maintenance \$K }\end{array}$ & $\begin{array}{c}\text { Ongoing } \\
\text { Maintenance \$K } \\
(2004-2010)\end{array}$ & $\begin{array}{c}\text { Replacement } \\
\text { Equipment \$K } \\
(2010)\end{array}$ & $\begin{array}{c}\text { Total Restart } \\
\text { \$K }\end{array}$ \\
\hline Standby & 96 & 10,500 & 883 & 11,479 \\
\hline Safe Store & 192 & 504 & 4,415 & 5,111 \\
\hline Lay-up & 0 & 0 & 8,830 & 8,830 \\
\hline
\end{tabular}




\section{CONCLUSION}

Options exist for the future of TAN and specifically the THS. Ultimately, the decision needs to be made to either fully support the TAN area or initiate a path forward for movement of the SNF and associated casks to INTEC and begin D\&D of TAN. Consideration given to cost, safety, and flexibility would indicate the concentration of all SNF to be accomplished at INTEC.

To make this a viable option, a number of items need resolution before initiation of transfers. The LOFT/Commercial fuel move from wet to dry storage must be accomplished. A cask storage pad at INTEC will need to be completed, and monitoring capabilities will need to be operational to support dry cask storage. Pad construction and roadway analysis should begin in the near future to accommodate earliest movement of SNF cask allowable from TAN. Facilities exist at INTEC for dealing with potential cask leaks. In addition when the SNF DSP facility planned for location near INTEC becomes operational, it may be used to respond to potential leaks in casks of certain sizes. This would require completion of an agreement for use of the SNF DSP to respond to potential leaks in a dry storage cask. An early estimate of operability of the SNF DSP facility is April 1, 2004.

After the casks are moved to INTEC, THS and its support facilities would be immediately placed into a Safe Store condition. Initial maintenance would be performed, and equipment would be taken out-of-service to minimize impacts to the environment, equipment, and personnel. Safe Store is the recommended and most cost-effective status in which to place the facility pending a new mission or sponsor.

A date for movement of SNF items from TAN to INTEC and an end date for potential new business opportunities need to be finalized. Close collaboration with and concurrence from the DOE-ID is essential for future planning at TAN. Before TAN is turned over to D\&D, every opportunity must be explored to find either complete or partial funding from sources within and outside the DOE complex in order to maintain the unique capabilities of TAN for DOE. Because of the unique capabilities of TAN in the DOE complex, it would be very time consuming and expensive to rebuild THS. Every effort should be taken to maintain the viability of this facility. Other programs that are currently unknown to management may exist and should be afforded the opportunity to use TAN.

The GPU/TMI abnormal waste needs resolution in the near future so planning efforts can begin for removal prior to turnover of the TAN-607 facility when SNF fuel moves are complete. The GPU/TMI abnormal waste has been at TAN for many years and must be returned to GPU or disposed of according to the current owner's requirements in order for the TAN facilities to be ready for D\&D.

Efforts should begin immediately to initiate D\&D of buildings other than the critical support facilities needed for the THS mentioned in the report Test Area North Readiness Plan Development, INEEL/INT-01-00096. Maintaining these excess facilities adds unwarranted liability to the INEEL and DOE. 


\section{Appendix A}

\section{Test Area North and Hot Shop Facility Description}




\section{Appendix A}

\section{Test Area North and Hot Shop Facility Description}

There are approximately 31 major buildings plus support structures, such as power, water, and disposal installations, located within the boundaries of Test Area North (TAN). The following lists those buildings or structures that are critical to the functioning of TAN-607 hot shop (THS):

- $\quad$ TAN-601 Guardhouse

- $\quad$ TAN-603 Steam Plant

- $\quad$ THS and associated attached facilities:

- $\quad$ TAN Hot Cell

- $\quad$ TAN-668, Heavy Equipment Cleaning Facility (HECF), and the special equipment services (SES) room

- $\quad$ TAN Storage Pool, which includes TAN-608, Water Filtration Building, and TAN-649, Water Filtration Building; Hot Cell Annex (HCA)

- TAN-633

- $\quad$ TAN Warm Shop

- $\quad$ TAN-607A

- $\quad$ The TAN exhaust stack (TAN-734) is outside the actual 607 structure

- TAN-610 Water Pumphouse

- $\quad$ TAN-612 Deep Well Pump House \#1

- $\quad$ TAN-613 Deep Well Pump House \#2

- $\quad$ TAN-623 Sewage Pumphouse.

The buildings and structures that are not critical to the functioning of the THS are:

- $\quad$ TAN-616 - The Liquid Waste Treatment Facility, which includes three tanks (V-1, V-2, and V-3) that are collectively referred to as TAN-1703

- $\quad$ Radioactive Parts Service and Storage Area (RPSSA) - This area includes two storage buildings (TAN-647 and TAN-648) and two concrete storage pads

- $\quad$ TAN-666-The Radioactive Liquid Waste Storage and Transfer Building

- $\quad$ TAN-790 - The Three-Mile Island (TMI)-2 Abnormal Waste Storage Pad 
- $\quad$ TAN-791—The Spent Fuel Storage Cask Testing Pad.

Other buildings and structures under TAN Operations (TANO) management are the office areas in TAN-607, TAN-615, TAN-618, and TAN-662. The Assembly and Maintenance Building, TAN-615, is used for maintenance work. TAN-618, Pad Data Collection Building, houses the equipment needed to monitor the casks on the storage pads. TAN-662, Gas Cylinder Storage, is used to store gas cylinders needed to support TANO activities.

\section{Hot Shop, Associated Equipment and Facilities Descriptions}

\section{TAN-607 Hot Shop}

The THS is a large, shielded high bay with overhead cranes, a large overhead manipulator, auxiliary wall-mounted manipulators, and other equipment for remote handling of radioactive material.

The walls and ceiling are constructed of ordinary concrete. The walls are $6 \mathrm{ft} 10 \mathrm{in}$. thick up to the lower ledge. Between the lower ledge and upper ledge, the thickness is reduced to $6 \mathrm{ft} 8 \mathrm{in}$. Between the upper ledge and the roof, the walls taper from a thickness of $4 \mathrm{ft} 4 \mathrm{in}$. to $2 \mathrm{ft}$. The ledges provide support for the overhead crane and manipulator tracks.

The roof is nominally 1-ft-thick concrete supported by trusses that span the THS on 18-ft centers. The concrete floor is supported on beams and is designed to support a $250-1 \mathrm{~b} / \mathrm{ft}^{2}$ load distributed uniformly over the entire area. An $18 \times 93-\mathrm{ft}$ section of the floor, encompassing the double railroad tracks, is reinforced to support extremely heavy loads; for example, the shielded locomotive (215 tons), cask transporter (up to 195 tons), and heavy transport truck (up to 100 tons). The other areas of the THS floor are also capable of supporting concentrated loads, but more care must be taken in placing the load to ensure adequate support. The floor system is made up of vertical piers, horizontal load-supporting grade beams, and the 1-ft-thick reinforced concrete floor slab. Each individual pier under the floor can support a load of approximately 75 tons, and the grade beams are proportionally sized. This feature allows large casks and other heavy items to be located off of the reinforced railroad track when specifically analyzed, with their weight properly positioned and distributed. The capacity of the floor over the utility tunnels is less than other areas because of the wider spacing of piers and beams. Use of the spent nuclear fuel cask transporter in the THS and placement of heavy loads is administratively restricted to the areas and locations specifically shown to be acceptable.

The west wall of the THS has a 28 -ft-wide $\times 33$-ft-high doorway that is used as a truck and locomotive entrance. Rail tracks enter through this doorway and extend $90 \mathrm{ft}$ into the THS. The west biparting doors are controlled from the south gallery. Limit switches and controls decrease door speed as the two sections approach fully open or fully closed positions. There is a "door open" indicator light on the control console.

Personnel enter through a shielded labyrinth located on the ground-floor level at the southwest corner of the THS. Access doors at each end of the labyrinth are interlocked electronically and must be unlocked from the master console or shift supervisor's office. Change room facilities (Room 115B) are located just outside the monitoring room (Room 103).

Shielded operating galleries are located at two elevations outside the north and south walls of the THS. These galleries constitute the control areas for remote operations in the THS; the operations are viewed through shielding windows. The following trouble indicators and alarms are located at the master control console located at the western end of the south operating gallery: 
- $\quad$ TAN Storage Pool low water level alarm

- $\quad$ Low-pressure breathing air indicator

- $\quad$ High-temperature breathing air indicator

- High and low exhaust fan differential pressure indicators (an indication of filter plugging or leaking)

- $\quad$ Low flow alarms for E7, E7A, and E8 (exhaust fans)

- $\quad$ Fans E7 and E7A running alarm to mitigate both fans operating at the same time

- $\quad$ Tunnel high water level alarm indicator.

Twelve ports for shielding windows are built at different elevations into the north and south THS walls. Nine of these ports contain windows and three contain high-density concrete shield plugs. These windows, originally built in 1954, are combination shielding type windows containing mineral oil, zinc bromide, and leaded glass. One window contains demineralized water instead of zinc bromide. The zinc-bromide solution is contained in a carbon-steel "tank" (with two glasses and four steel sides), that also serves as a frame for the windows. Numerous layers of paint protect the steel from the zinc bromide. An expansion area at the top of each window permits thermal expansion and contraction of the zinc bromide.

The windows are flush with the walls on the hot side and sealed into the walls with high-density concrete grout. Steel shot occupies the space between the frames and the windows to prevent any radiation from streaming through the voids. All penetrations through the wall around each window are shielded with steel shot and closed off at each end when a port is not being used. Those penetrations that are used to pass various cables from the operating gallery into the THS are backfilled with steel or lead shot that is held in place by steel or lead wool according to TAN requirements. These requirements ensure that if any penetrations are modified, they are properly backfilled to ensure that the THS will remain well shielded from an inadvertent criticality accident.

The shielding capacity of window $G$ is less than the other shielding windows, because the shielding capability of demineralized water is less than that of zinc bromide. However, adequate attenuation is still provided by this window. Also, the physical construction of the THS prevents fuel bundles and other high radiation sources from being moved within $3 \mathrm{ft}$ of window $\mathrm{G}$.

\section{Special Equipment Service Room}

The SES room is an extension on the eastern end of the THS, separated from the THS by a set of large shielding doors. The finished floor elevation of the SES room is $13 \mathrm{ft}$ above the THS floor, and a 5-ft-thick concrete parapet rises $13 \mathrm{ft}$ above the SES room floor.

A set of 5-ft-thick biparting concrete shield doors, normally located in recesses in the north-south walls, rides on rollers across the parapet to isolate the SES room from the THS. These doors extend from the parapet to the roof. The rails for the bridge crane and the overhead manipulator are hinged and swing out of the way when the doors are closed. Controls for opening and closing the doors are located in the SES room-operating gallery, an extension of the THS south operating gallery. The SES room-operating gallery has been shown to be well shielded from an inadvertent criticality for TMI-2 canisters. 
The 3-ft-thick concrete slab that forms the floor of the SES room also covers a personnel access tunnel connecting the equipment and work areas on each side of the THS. A 13-ft-deep service pit, approximately $12 \mathrm{ft}$ wide and $15 \mathrm{ft}$ long, extends through the floor slab down to the THS floor level. This pit contains a high-efficiency particulate air (HEPA) filter bank used for exhausting the SES room by way of the E7 and E7A fan system. A viewing window is located in the south wall just above a remote control station.

Personnel enter the SES room through a manually operated, rolling shield door that opens from the operator gallery.

\section{Heavy Equipment Cleaning Facility}

The HECF is insulated, heated, and weather-tight. It provides a waiting area for trucks and components scheduled to enter the THS. The HECF measures approximately $70 \times 40 \mathrm{ft}$, with an eave height of $40 \mathrm{ft}$. A vehicle door at the western end offers clearance identical to the THS doors, with a measurement of $28 \times 33 \mathrm{ft}$. The entire facility provides a weather break to allow the THS doors to be open during inclement weather conditions.

A high-pressure cleaning unit is available to wash heavy equipment and cask assemblies. This unit is also used to de-ice heavy equipment during the winter. Water from this system drains to TAN-711, Sanitary Treatment Plant. A snorkel system in the facility vents vehicle exhaust to the outside.

\section{0/10-Ton Overhead Crane}

The 110/10-ton overhead crane is the major lifting device for handling spent nuclear fuel, casks, and other heavy equipment in the THS. The 110/10-ton crane-bridge runs on 100-lb building rails mounted on the upper ledges of the THS and SES room walls. The rails, which are $195 \mathrm{ft}$ long, run the full length of the THS and SES room. The rails are hinged at the entrance to the SES room and swing out to allow the SES room shielding doors to close and are interlocked to prevent crane operations over open rails.

The 110/10-ton overhead crane is a radio-controlled unit and consists of a bridge spanning the full width of the THS, a trolley mounted on the bridge, and two hoists mounted on that trolley. The larger hoist is rated for 110 tons, and the other is rated for 10 tons. Both the 110- and 10-ton hooks are continuously free swiveling and are designed for use under water in the Storage Pool vestibule. The 110/10-ton crane hooks and emergency-load-release mechanisms have been designed for remote operation.

\section{Overhead Manipulator}

The overhead manipulator (O-man) is a heavy duty, bridge and trolley mounted, remote electromechanical manipulator. A set of rails mounted on a wall ledge below the 110/10-ton overhead crane carries the manipulator bridge the full length of the THS and SES room. Bridge rails, supporting a trolley, carry the O-man the full width of the shop. Trolley and bridge speed is variable up to 50 and $100 \mathrm{ft} / \mathrm{min}$, respectively.

The O-man is capable of handling a 500-lb load. It can grasp and manipulate tools and has a shoulder hook that can support up to 5,000-lb up to a height of approximately $30 \mathrm{ft}$. The $\mathrm{O}$-man is controlled at THS and SES window control stations. The control stations are electrically interlocked to prevent simultaneous control from more than one station. 


\section{Wall-Mounted Manipulators}

Three wall-mounted, electromechanical manipulators in the THS are capable of performing tasks throughout most of the THS, excluding the SES room. The hoist provided for each manipulator is an extending tube crane with an extension of 92 in. At the end of the crane, a heavy-duty gearbox acts as a shoulder pivot. A 60-in. extension is attached to the gearbox. A shoulder, attached to the end of the extension, rotates a manipulator arm. The shoulder hook is rated for a 150-lb load with the extension tube vertical. The entire manipulator is capable of lifting $150 \mathrm{lb}$ in any position.

\section{THS Turntables}

The THS can be equipped with two turntables that rotate large pieces of equipment for inspection and assembly (disassembly) with remote manipulators. The turntables are located in pits along with rails, pivot assemblies, and drive motors. Each turntable can support a 60-ton load over three supporting pads on each side of the turntable. The pads are drilled, tapped, or doweled to accommodate special fixtures used for supporting and holding the load.

\section{North Silo}

The THS North Silo provides storage for dry spent nuclear fuel elements and lead test assembly tritium producing burnable absorber rods (TPBARs). It consists of a shielded lid and two concentric upright steel cylinders placed over and around the north turntable pit. The turntable, rails, pivot assembly, and drive motor have been removed from the north turntable pit and replaced by a load-spreading device of criss-crossed, 14 in.-wide flange carbon steel beams.

The outer wall is $0.25 \mathrm{in}$. thick and the inner wall is $0.5 \mathrm{in}$. thick. The 6-in. annulus between the two concentric upright steel cylinders is filled with lead shot, and the lid contains lead slabs on a steel plate between the I-beam supporting structure. The silo has an outside diameter of $20.75 \mathrm{ft}$, exclusive of the external wall strengthening beams. The inside diameter is $19.7 \mathrm{ft}$, but vertical beams attached to the inside of the inner silo wall, for structural stability and lid support, reduce the inside clearance to $18.8 \mathrm{ft}$. Both silo walls are constructed of carbon steel. The silo height is approximately $18.5 \mathrm{ft}$. An inflatable seal, allowing an inert atmosphere to be retained inside the silo seals the shielded lid to the silo walls.

Canister storage racks located in the two north quadrants of the silo provide fuel element storage. The racks are designed to hold spent nuclear fuel elements in a vertical position with a minimum 16-in. center-to-center spacing. Each rack is a tubular frame with the top, bottom, and center spacing plates. Storage items are contained in sleeves that are open-ended and suspended by flanges from the top spacing plate. The center and bottom plates act as guides for insertion of the sleeves.

Shield plugs have been placed into some peripheral storage positions. The lead-filled shield plugs are made from $8 \times 8$-in.-square carbon steel tubing with a wall thickness of 0.5 in and a bottom and top closure plate. The interior space is $13.75 \mathrm{ft}$ in height and filled with the same type of lead shot used in the wall. A lifting bail at one end permits the plug to be inserted into the storage rack position with the 110/10-ton overhead crane. The overall weight of each plug is approximately 3,000 lb. Twenty-one of these plugs have been built and installed in the two rack quadrants, leaving 17 positions open for radioactive material storage. Plugs can be installed, relocated, or removed as necessary to provide adequate shielding for specific material loadings.

The exterior shield walls consist of two high-density concrete slabs that are approximately $10 \mathrm{ft}$ high, $18 \mathrm{ft}$ long, and $10 \mathrm{in}$. thick, and weighing approximately 16.5 tons each. The exterior shield walls are located along the east and west sides of the silo at right angles to the north wall of the THS. These 
walls are anchored to the floor and to the north wall of the THS and are braced to the floor at the south end of each wall. Because of interference from other THS equipment, the west shield wall is approximately $2 \mathrm{ft}$ from the silo wall. The east shield wall is $5.5 \mathrm{ft}$ from the silo wall and encloses pedestal $\mathrm{J}$ between it and the silo. It has an additional steel wall attached at a right angle to its south end. This steel wall is $6.2 \mathrm{ft}$ thick and is as tall as the concrete wall. It serves to reduce radiation "shine" through the otherwise large gap between the concrete shield walls and the silo.

A neutron shield wall made of double thickness 2 -in. $\times 4$-ft $\times 8$-ft polyethylene slabs can be placed in a flat "V" shape along the south side of the silo or can be removed to allow equipment to move further into the shop. The wall is attached to an angle iron frame for support. Except for a narrow personnel access gap on each end, the wall connects the two concrete shield walls to surround the silo. The apex of the "V" intrudes a few inches into the four-rail track at the south side of the silo.

\section{Rail System}

A four-track, standard gauge railroad system between the THS, Contained Test Facility, and other facilities at TAN extends $90 \mathrm{ft}$ into the THS through the west biparting shield doors. Flatcar-mounted systems and large equipment were moved into or out of the THS with a shielded locomotive or a trackmobile available for this purpose. A 90-ft turntable, located just west of the THS, facilitated maneuvering flatcars between the TAN facilities served by the railroad system.

This system is not currently operational because of maintenance deficiencies. However, it could be put back into service if the required corrective actions were performed. The majority of the corrective action includes replacement of track and refurbishment of the turntable.

\section{Service Pedestal}

Nine floor-mounted service pedestals, one in front of each window, provide one or more of the following services. The pedestals are modified as needed to provide the combination of services required by the process.

- $\quad$ Air-90 psi-Snap Tite or equivalent, coupling 3/4-in. AVSRN-12

- $\quad 120-\mathrm{V} / 30$-amp, three-pole receptacle (one pole for ground)

- $\quad 120-\mathrm{V} / 30$-amp, five-pole receptacle (tool power)

- $\quad 208-\mathrm{V} / 30$-amp, three-phase, four-pole receptacle

- Demineralized water-1-in. pipe-100 psi (supply and return); 2-in. Snap-Tite and 2-in. Wiggins or equivalent

- $\quad$ Raw water-2-in. pipe, 2-in. Snap-Tite or equivalent connector

- Treated water-2-in. pipe, 2-in. Snap-Tite or equivalent connector

- $\quad 120-\mathrm{V} / 30-\mathrm{amp}$, industrial-type outlet

- 208-V/30-amp, industrial-type outlet

- 480-V/60-amp, three-phase, industrial-type outlet 
- Breathing air-100 psi-0.5-in. Schraeder or equivalent quick connect/disconnect valves.

In addition to the service pedestals, there are ports ranging in size from 2 to $12 \mathrm{in.} \mathrm{surrounding} \mathrm{each}$ window. These are normally plugged and sealed but could be used for providing additional services to the THS. Another 56 normally plugged and sealed ports penetrating the walls between the equipment galleries and the THS could also be used for bringing in services.

\section{Cask Work Platform}

A steel scaffold has been constructed to provide a secure work platform for personnel around the tops of various storage and shipping casks in the THS. This platform is at an elevation of approximately $13 \mathrm{ft}$ above the THS floor. It is equipped with guardrails, toe boards, and stairs. Two horseshoe-shaped holes at each end of the rectangular platform provide positions for upright casks to be placed. The smaller of the two holes is approximately $7 \mathrm{ft}$ across and is designed to accept shipping casks. The larger hole is approximately $10 \mathrm{ft}$ across and is used for the larger diameter storage casks. Removable sections of platform are installed across the open ends of the horseshoes after a cask has been put in place to provide secure access completely around the cask top. The platform structure may also be used as a temporary storage location for various grapples (and other lifting devices) and tools.

\section{Storage Pool Vestibule}

The TAN Storage Pool that is used to store radioactive components is located adjacent to the north side of the THS. A submerged passageway under the THS wall connects the main Storage Pool to a 24-ft wide $\times 25$-ft long $\times 24$-ft deep pool vestibule, located in the northeast corner of the THS. The underwater passageway is $19-\mathrm{ft}$ high and $24-\mathrm{ft}$ wide, and the top of the passageway under the shield wall is $5 \mathrm{ft}$ underwater to protect the main pool area from radiation sources in the THS.

The TAN Storage Pool and Storage Pool vestibule are connected by an underwater rail system and pool transfer cart $11 \mathrm{ft}$ wide and $13 \mathrm{ft}$ long, which is powered by an electric, variable-speed winch.

Radioactive components can be lowered onto the pool transfer cart with the 110/10-ton overhead crane and transferred between the Storage Pool vestibule and Storage Pool.

In support of the TMI Program, a 1-in.-thick steel plate has been installed on the western side of the vestibule floor to prevent pool damage in the unlikely event of a canister drop.

\section{THS/Cell Transporter}

The THS/Cell transporter system is designed to remotely move objects between the THS and the TAN Hot Cell. It consists of a load-carrying pallet supported on rollers and propelled by a rack and pinion-drive system. It is remotely controlled from a portable plug-in control station at a window in the Hot Cell control gallery. The transporter system is limited to a load of 4,000 lb.

\section{THS Tunnel}

A tunnel under the floor of the THS provides access to all of the service pedestals, turntables, and control wiring and piping. The tunnel is sloped to drain into a sump located at the entrance point. A float switch in the sump activates a ringing bell, and a light at the main console if water reaches the top of the sump. A submersible pump located in the sump must be manually activated to transfer water to TAN-666, the Radioactive Liquid Waste Transfer and Storage Building. 


\section{TAN Hot Cell}

The TAN Hot Cell, located adjacent to the southeast corner of the THS, is a conventional, shielded, remote-manipulator laboratory used for specialized disassembly, inspection, and examination. The cell floor is $2.75 \mathrm{ft}$ below the THS floor level. The cell measures $10 \times 35 \mathrm{ft}$, with a ceiling height of $20 \mathrm{ft}$. The walls are $4 \mathrm{ft}$ thick and are made of high-density concrete and lined with stainless steel sheets. The cell is designed for installation of a false floor to elevate equipment as needed. The main floor has drains to carry contaminated liquids used in decontamination operations to TAN-666, the Radioactive Liquid Waste Transfer and Storage Building. Materials are transferred between the Hot Cell and the THS through a biparting, $4.5 \times 8.25$-ft, lead-filled shield door by way of the THS/Cell transporter system.

There are five identical viewing windows in the TAN Hot Cell; four in the west wall (N, P, Q, and $\mathrm{R})$ and one (S) in the east wall. The shielding provided by the windows is nominally the same as the 4-ft-thick, high-density concrete walls. The windows are designated "Type 1" and have the following configuration: one pane of Type E white-water lime glass, 1 in. thick; two panes of Type D leaded glass, 4-1/16 in. thick; ten panes of Type B leaded glass, 4-1/16 in. thick; and one pane of Type A leaded glass, 3 in. thick.

Spaces between the panes of the windows are filled with mineral oil for viewing clarity. The shielding calculations did not take credit for the mineral oil between the panes. Voids around the windows are filled with steel shot to shield radiation streaming.

Personnel can enter through a doorway in the south wall of the cell. The 4-ft-thick, high-density concrete shield door, which is set in a shallow trench, rolls on free rollers that ride on rails in the floor of the trench. An enclosure has been built around this shield door to prevent the spread of contamination when this door is used.

Through the shield wall and above each of the five viewing windows, two ports are provided for mounting hand-operated master-slave manipulators. The ports above the four windows on the west wall are equipped with seven master-slaves. Two master-slaves are provided at the viewing window on the eastern side of the cell.

Two electromechanical bridge mounted manipulators span the TAN Hot Cell on the same set of rails. A 2-ton-capacity chain hoist is also provided on each bridge. Switches that are actuated before the bridge reaches the end of the rail limit travel along the bridge. The carriage travels east-west approximately $63 \mathrm{in}$. from one end stop to the other by riding on rails welded to the top of the bridge beams. The telescoping tube hoist is mounted on and projects beneath the carriage. A manipulator arm and wrist, which can support either a standard manipulator hand or a hook assembly, are attached to the tube hoist.

Three wall periscopes, two of them mounted on the west wall of the Hot Cell and the third on the east wall, permit viewing and photography inside the Hot Cell within a solid angle of 180 degrees, centered about the objective end. A shield plug is mounted behind the joint between the vertical and horizontal arms of the periscope to reduce radiation streaming through the penetration.

\section{TAN Storage Pool}

The TAN Storage Pool that is used for underwater storage of fissile and radioactive materials is located in TAN-607 adjacent to the north side of the THS. The primary shielding for these items is the water covering them; thus, the Storage Pool room is not constructed as shielding but shelters the Storage Pool from the environment. 
The fissile material consists mostly of spent nuclear fuel assemblies; the majority of the radioactive materials consists of canisters full of TMI-2 core debris. Various storage devices, such as vertical and horizontal spent nuclear fuel racks, nonfuel bearing component baskets, and six-pack modules, are used to store the items in the Storage Pool. These storage devices are designed for criticality safety and seismic stability.

The east half of the Storage Pool and a portion of the west half were reserved for the storage of core debris from the damaged TMI- 2 reactor. The debris is stored in specially designed canisters placed in six-pack modules, which hold a $2 \times 3$ array of these canisters. The rest of the TAN Storage Pool is used for storage of nuclear reactor spent fuel consisting of: (a) fuel from the decommissioned LOFT reactor, which is stored in two modified TMI-2 modules; (b) spent nuclear fuel from various research programs sponsored by the U.S. Nuclear Regulatory Commission (NRC) and DOE, which includes partial and complete commercial reactor fuel bundles; and (c) test fuels from reactor tests conducted at other Idaho National Engineering and Environmental Laboratory (INEEL) facilities (loose fuel rods from these fuel elements are stored in a $10 \times 10$ - $\mathrm{ft}$ vertical rod storage rack and a modified horizontal rack). In addition to these fuels, some reactor non-fuel bearing component materials for DOE programs are stored in the pool.

The TAN Storage Pool measures $48 \times 70-\mathrm{ft}$ and is $24-\mathrm{ft}$ deep. The Storage Pool is connected to the Storage Pool vestibule in the THS by a $24 \times 19$-ft passage under the THS wall. The north wall of the THS extends down $5 \mathrm{ft}$ into the pool to shield the pool area against radiation sources in the THS.

A 13-ft long $\times 11$ - $\mathrm{ft}$ wide pool transfer cart is used to transfer items between the Storage Pool and Storage Pool vestibule. The cart is rated for 60 tons and rides on a pair of 91-ft long rails laid in a 3-ft deep trench at the bottom of the Storage Pool and Storage Pool vestibule. The pool transfer cart is powered back and forth along the rails by an endless cable system driven at speeds up to $40 \mathrm{ft} / \mathrm{min}$ by an electric winch located out of the water at the north end of the Storage Pool. The top of the pool transfer cart is approximately 2 in. above the floor level of the Storage Pool. Materials are loaded on and off the pool transfer cart using the 110/10-ton overhead crane in the THS and 15-ton bridge crane within the Storage Pool area.

A work area for personnel surrounds the pool (except on the south end), providing access to the pool parapet and cranes in the Storage Pool area. Two cranes serve the Storage Pool area: 15-ton bridge crane and 30-ton tram hoist. The 15-ton bridge crane spans the Storage Pool on 75-ft rails mounted on the pool side parapets.

Two 500-lb capacity personnel platforms are available to provide greater visual guidance for work being performed with the 15-ton bridge crane. Travel limits for the bridge vary from 6 to $9 \mathrm{ft}$ from the north and south bumpers, depending on where the travel limits are set. The travel limits for the trolley are adjustable to within 18 in. of the rail's end. No lower-limit switch exists for the hook motion; however, an upper limit switch prevents the hook and rigging from colliding with the hoist. Additional interlock is connected to a remote area monitor (RAM), which disables the "up" motion if the RAM setpoint is exceeded. An override-key switch is provided to continue the "up" motion if conditions permit or if the situation requires such action. The 15-ton bridge crane is controlled by one of two six-button control pendants, one on each side of the hoist trolley. Electrical interlocks prevent dual control. The hoist, trolley, and bridge each have two buttons used to operate them. Motion speed increases with increased pressure on the pushbuttons.

The 30-ton tram hoist has rails that extend from the truck-loading platform through doors on the western side of the Storage Pool building to about $11 \mathrm{ft}$ over the pool. The 30-ton tram hoist provides a means for bringing casks and other large objects directly into the Storage Pool. However, it is not used 
because it does not provide adequate clearance over the Storage Pool parapet. The 30-ton tram hoist is tagged out, and there are no plans to put it back into service.

To maintain water quality, the TAN Storage Pool is equipped with a water treatment system. Also, materials placed in the Storage Pool are evaluated for high levels of contamination and damaged or exposed spent nuclear fuel to minimize cross-contamination of the water. If necessary, such materials are encapsulated in special containers.

The purification system consists of a circulation pump, located at the north end of the Storage Pool room, and two filters and a resin ion-exchange block, located in the water filtration buildings (TAN-608 and TAN-649), which are connected to TAN-607 at the north end of the Storage Pool. The pump circulates the pool water through the two filters and the ion exchange block and back to the Storage Pool. The ion-exchange columns are enclosed in a disposable concrete block to provide shielding. During changeout of the ion-exchange columns, the whole block is removed, and a new column is installed. The used block is transported to a waste disposal area.

The water volume in the TAN Storage Pool changes based on evaporation; movement of items into, out of, and within the pool; and makeup. In addition to manual checks, a leak detection system treats the water in the pool as a control volume and determines changes in the level of the pool based on the volume of water entering or leaving the control volume. A series of sensors and transducers provides the information required in calculating the evaporation rate for the pool and to measure the makeup water added to the pool. The estimated pool level is then compared to the actual measured level of the pool. If the measured level is consistently less than the estimated level of the pool, then water is leaving the pool other than by evaporation. If the loss of water is not accounted for by activities in the pool, then a leak is present. The system is capable of detecting leaks larger than 40 gpm within 15 minutes of initiation of the leak. It can also detect leaks as small as 25 gph when monitored over a 24-hour or longer period.

If a leak is detected, water can be added to the pool at a rate of approximately 25 gpm from the 10,000-gal tank of demineralized water. If the demineralized water system cannot maintain the water level, emergency injection water is provided from the TAN firewater system. The injection water fill-line enters the Storage Pool room through the east wall and extends approximately $6 \mathrm{ft}$ over the edge of the Storage Pool. The isolation valve is located in Room 220 and is opened manually.

The TAN firewater and emergency injection system receives water from a 500,000-gal storage tank filled from underground wells. Firewater pumps supply a main firewater header for all of TAN. The two electric-powered pumps each have a 1,000-gpm capacity. Another pump is diesel-driven with a 1,500 -gpm capacity and receives power from the TAN-603 diesel generator if commercial power is lost.

\section{Hot Cell Annex}

The HCA, located in TAN-633, adjoins TAN-607 on the north side and consists of four adjacent hot cells with pass-through capability between cells and the necessary support areas. The HCA is out of service.

Identical oil-glass laminated viewing windows are located in the west wall of each cell. The windows are designated as Type 1 (as discussed for the TAN Hot Cell). Each window contains six panes of glass. Spaces between the panes typically filled with mineral oil for viewing clarity. Gamma-ray attenuation through the HCA viewing windows is approximately equivalent to the 3-ft thick, high-density concrete wall. 


\section{TAN Warm Shop}

The TAN Warm Shop is located adjacent to the south wall of the THS. It is approximately $80 \mathrm{ft}$ long and has a usable floor area that is approximately $40 \mathrm{ft}$ wide. The four-track railroad system extends approximately $75-\mathrm{ft}$ into the Warm Shop from the west biparting doors.

The Warm Shop area is serviced by a Warm Shop bridge crane traveling on rails that are $78 \mathrm{ft}$ long, spans $63.7 \mathrm{ft}$, and are $39.25 \mathrm{ft}$ from floor level to the top of the rails. The capacity of the main hook is 30 tons, and the capacity of the auxiliary hook is 5 tons.

The floor of the Warm Shop is of similar construction to the THS and has a high load capacity on the railroad track area. An analysis was conducted that shows that the track area will support a cask of up to 75 tons centered on the rails. The analysis also shows that the cask transporter, with a combined load and vehicle weight of 132.5 tons, can be operated in an area centered on the tracks.

The TAN Warm Shop is a registered hazardous waste accumulation area. Also, the Warm Shop is operated as a fissile material control area. However, fissile material is restricted to approved shipping or storage casks that remain sealed while in the Warm Shop.

\section{Decon Shop (TAN-607A Rooms 159, 160, and 160A)}

Rooms 159, 160, and 160A are located in the southwest corner of TAN 607. The approximate room dimensions are $42 \times 36 \mathrm{ft}$ for Room $159,8 \times 36 \mathrm{ft}$ for Room 160, and $13 \times 36 \mathrm{ft}$ for Room 160A. Room 159 has a 30-ton bridge crane and Room 160A contains the electrical ventilation systems (currently out of service) and steam pipe systems for Room 159.

From 1957 to about 1987, Room 159 was used to decontaminate equipment; Room 160 was an anticontamination clothing change room; and Room 160A contained ventilation, electrical, and steam distribution equipment for room 159. All three rooms were taken out of service in 1987. Recent remediation efforts in these rooms involved removing decon equipment from Room 159; decontaminating the room and equipment, which included replacing the HEPA filters in the HEPA bank; and removing asbestos containing material from the steam pipes. Some fixed contamination in Room 159 has been painted over on the floor and up to $8 \mathrm{ft}$ high on the walls.

Current and planned uses for Room 159 are cask dismantlement, storage of contaminated and noncontaminated materials, and storage, handling, and repackaging of mixed hazardous waste. 
Appendix B

Costs Associated with INTEC Option 
B-2 


\section{Appendix B}

Costs Associated with INTEC Option

\begin{tabular}{|c|c|c|c|}
\hline Task & $\begin{array}{c}\text { Supplemental } \\
\text { Documents }\end{array}$ & $\begin{array}{c}\text { Subtotals } \\
(\$ \mathrm{~K})\end{array}$ & $\begin{array}{c}\text { Total Cost } \\
(\$ \mathrm{~K})\end{array}$ \\
\hline $\begin{array}{l}\text { INTEC concrete storage pad } \\
(45 \mathrm{ft} \text { wide } \times 140 \mathrm{ft} \text { long } \times 2 \mathrm{ft} \text { thick }) \text { construction }\end{array}$ & & & 465 \\
\hline Design and specification & & 75 & \\
\hline Pad construction & & 350 & \\
\hline Alarm house construction & & 40 & \\
\hline New roadway inside fence to pad & & & 345 \\
\hline Design and specification & & 20 & \\
\hline Construction (heavy load roadway) & & 325 & \\
\hline SAR for new facility & SAR Document & & 36 \\
\hline Environmental assessment & & & 10 \\
\hline Cask transporter/section for each cask & & & 100 \\
\hline Five individual SARs & & & 600 \\
\hline Procedures for cask movement using transporter & & & 50 \\
\hline Operational Readiness Review & & & 250 \\
\hline NRF bridge study and reinforcement & & & 150 \\
\hline Bridge EDF & & 75 & \\
\hline Reinforce bridge & & 75 & \\
\hline Transport casks from TAN to INTEC & & & 194 \\
\hline Remove overhead barriers & & 50 & \\
\hline Prepare transport documents/training & & 50 & \\
\hline Load casks at TAN (5) & & 30 & \\
\hline Transport to INTEC (5) & & 40 & \\
\hline Return transporter to TAN & & 24 & \\
\hline INTEC infrastructure & & & 500 \\
\hline EDF/overhead clearance/new gate & & 500 & \\
\hline Subtotal & & & 2,706 \\
\hline Mgmt res.@35\% & & & 941 \\
\hline Project mgmt@15\% & & & 400 \\
\hline Grand total & & & 4,053 \\
\hline
\end{tabular}




\section{Assumptions:}

- $\quad$ The new road within the fence at Idaho Nuclear Technology and Engineering Center (INTEC) will require drawings and a specification.

- $\quad$ The safety analysis report (SAR) for the new facility should be very similar to the SAR used at Test Area North (TAN). This should entail a rewrite of the existing TAN documentation.

- $\quad$ Each cask is expected to have an individual SAR. Each cask has a different manufacturer, and each cask has a different structure. None of the casks were certified to transport fuel.

- $\quad$ Modify the existing procedure to move the casks from TAN to INTEC.

- $\quad$ Cost estimate based upon the Material Test Reactor Operational Readiness Review and adjusted for additional complexity and the 5 different casks to be moved.

- $\quad$ Because the transporter is shorter than the Naval Reactor Facilities bridge, an additional temporary support will be needed to support the concentrated load.

- Movement to INTEC is expected to be a slow process - the cask transporter is 30 feet high and weighs 58 tons empty.

- $\quad$ Preliminary review of the INTEC roads and the overhead clearances indicate that the best way to handle the transporter would be to have a new gate built along the south fence line of INTEC. This will shorten the path for the transporter to carry the casks to the interim storage pad at INTEC or to the Spent Nuclear Fuel Dry Storage Project and protect the INTEC roads. 